\title{
Implications Status Alteration and Nāẓir Position on Wealth Endowments Producivity
}

\author{
Fikfik Taufik $^{1}$ \\ 1STAI Sabili, Bandung, Indonesia. \\ Email: senjaelmakhfi@gmail.com
}

\begin{abstract}
:
Endowments are Aaliyah worship which has the noble social function to comply the various things that are relating the physical requirement and spiritual of society. To create the social function, there was appointed person or group of people, and on behalf of the individuals or legal entity optimally in charge of managing the endowments property. The endowment is an Islamic legal institution which was legality is based on the Qur'an and Hadith. In addition, regarding the lawmaking of endowments are also sourced from ijtihad, which focuses on mashed terms of shari'a, those are for creating the beneficence and strange on damage. Nāzir alteration has to own the legality either form fiqh consideration (jurisprudence) or legislation and also have to be considered how far the conformity of alteration practice with fiqh (jurisprudence) and legislation, The alteration Nāzir endowments as one of the efforts to optimize the wealth endowments management it's needed to be examined further. On this observation, it is used a qualitative approach with the research resources (research library), and in-depth interviews. The normative data which constituting a fact on the ground that has been collected then analyzed and also compared. This observation results explained that the alteration of Nāzir endowments also has the legality, either figh (jurisprudence) or the legislation. The implementation of its changes is also implicated on optimizing the endowments property management, both in terms of results, or in terms of management.
\end{abstract}

Keywords: Nāẓir Alterations, Expediency/beneficence (maslahah), litihad, Productivity.

\section{A. INTRODUCTION}

The endowments (waqf) as a part of Islamic law which has a social dimension, it's existence on the islam economic instrument could be called as exclusive and strategic one (Babacan, 2011; Cf., Rozalinda, 2015; Ab Hasan et. al., 2015; Mohamad, Zulkifli, 2015; Purwanto et. al., 2016; Athoillah, 2013; and Rosadi \& Athoillah, 2015). The endowments have already known by the society long time ago as one of jariyah deeds which are crucial for the social development, economic, and culture in order to improve the welfare of the community (Salarzahi et. al., 2010; Chowdhury et. al., 2011).

The purpose and endowment function is contained on the constitution No. 41 of 2004 on the endowments in Article 5. there has already mentioned that the general purpose or the endowments function is creating the potential and the economic benefits of endowments property for the worship interest and advancing the general welfare.

BWI (Badan Wakaf Indonesia [Indonesian Waqf Board]) Regulations No.4 of 2010 on Guidelines the Management and Development of Property endowments article 3 paragraph 2 expressly states that 
the management of endowments property must be done productively. That the law existence is directing the endowments management professionally either by individuals, organizations, and legal.

Endowments Nāzir as the subject of endowments property manager, has an important role in developing the endowments property .way of treating nāz̧ir on the endowmnents property willdetermined the qualities and quantities of the endowments property utilization. A nāzir also who will affect the attractiveness of the endowments perpetrators for donating their wealth through the endowments product packaging offered. Therefore, it's needed a professional working team (Diharto, 2016; Dyarini \& Jamilah, 2016).

A nāzir confessions endowments organizations or institutions and legal entities on the law No. 41 of 2004 on endowments, is a government effort forms to optimize the management and productivity of endowments property. The jurisprudence books it's doesn't mention there was Nāzir but, it's only specifying the Nāẓir terms. For example in al-Fiqh al-Islami wa 'Adillatuh, nāẓir endowments is required all grown up and has skills on managing endowments property (Zuhaily, 1985).

In fact, based on the Law No. 41 of 2004 Article 10, paragraph 1, stated that the terms Nāzir endowments are: a. Indonesian citizens; b. Muslim; c. Adult; d. Amanah; e. able on physically and spiritually; and; f. Not deterred the legal actions. Definitely, it's terms weren't ever be given by Allah and His Messenger. the determination of these requirements are based on general rules of Sharia formulated through ijtihād, related by maqāșid al-sharīa (Cf., Ahmed, 2011).

Certainly, the concept of maqāșid al-sharīa it's closely relevance with mașlaḥa theory because whether there's or no it's maslahah term is determined by whether fulfilled or not the maqāșid alshari'a. The mașlaha rule as law theorem, can be used as an excuse recognition or even launching institution of nāẓir endowments and legal entities fiqhiyya (Dusuki \& Abdullah, 2007; and Sirat, Shafiai, 2016).

Public attitudes which bestows the right management of endowments to the institutions or law entities on the basis of maslahah, should get on the supporting the relation into the law is a legal entity. BWI Regulations No. 3 Year 2008 on registration prodecures and reimbursement nāzir endowments immovable property such as land has arranged the transfer rights management of endowments. Delegation of endowments management rights of individuals to Nāzir institutions is considered important because nāz̧ir institution or legal entity will be able to manage the endowments property professionaly more. In addition, the guidance and supervision BWI for a nāz̧ir institution or legal entity will be easier because a nāẓir institutions should have a higher level accountabilities in reporting the ultilization of endowments property of the individual nāzir.

The conclusion, that nāzirinstitutions or organizations that more propesional of the individuals nāzir, would be stronger if their research is execute on one of the endowments object that ever managed by the individuals nāẓir ,then by nāẓir institution, or initially by nāẓir institutions, then by a larger agency. then We will be able to see whether or not, there were the significant developments on endowments property, if we compare the conditions endowments before and after the nāzir transfer has taken place. Therefore, this study it's will be extremely important done.

\section{B. METHODS}

Considering the issues that will be raised on this study relating to the status alterations and status of nāzir endowments according with Jurisprudence (figh) and legislation and it's Implications on 
Treasure Endowments productivity, then, this study is included to the type of juridical-normative, ie the literature data search of the theory (proposition) and the concept of nāzir endowments from jurisprudence books, and other research methods course use any juridical-normative research methods. This research was supported by the finding of facts and empirical reality on the ground in the neighborhood which concentrate of Jam'iyya Islamic Union.

Phenomenological (approach) that will be used is a qualitative approach. Theories, concepts, and the empirical data that found on the field which were presented descriptively, by describing the characteristics of the data accurately accordance with the nature itself, or the relation of these issues is, that the authors sought to systematically describe the theories and concepts Nāzir and the facts of it's field.

Data collection is related to the theorem and law norm which done by gathering thoughts of fiqih scholars and Islamic law, especially Ibn al-Qayyim, Wahbah Zuhaili, and Abu Zahra. While the related thing of nāẓir endowments concept are done by collecting fatwas and jurist's opinions, especially of the four schools, as well as legislation.

Events recording and things or particulars, either partially or wholly on nāżir role in managing endowments property and its implications on endowments property productivity is done by the observation, interviews and document study.

The study documents is a search of historical data that's reveals things it was happened on the past, both concerning the status utilization of nāzir endowments, productivity, as far as the endowment products that's ever offered to members Jam'iyya Islamic Union in particular.

Data analysis is done in two ways: first, normative analysis, namely by reviewing the fiqhiyyah opinions and legislations relating on nāz̧ir endowments; and factual analysis data, which is learned the endowments documents and then compared with the normative rules to see the conformity between both of them, as well as studying the management pattern of endowments property to see how far the effects on the alteration of nāzir endowments.

\section{RESULT AND DISCUSSIONS}

\section{Legal basic of nāẓir alterations}

The Conception of Islamic law, and the basic legal framework established by the God (Moustafa, 2014), it's not just regulate the human relationships with other human beings and community objects, but also other relations, such as the human relationship with God (Ali, 1990).

Islamic law is based on a naqli propositions and 'aqli propositions (Winarno, 2016). Naqli propositions is al-Quran and Hadith, as for the 'aqlī argument is ijtihād which include a qiyās, mașlaḥa mursala, istiḥsān, istișhab, and dzarāi'. ljtihad existence as a law propositions is one of the reasons that make Islamic law, in the jurisprudence sense, it's more dynamic (Hashish, 2016). Islamic law is evolved gradually since the Prophets era and his companions, and One of the reason that why islamic laws is growing up because of the people's needs are constantly evolving to know the various law on the new problems to regulate the human relationships and determine rights and it's obligations each of them, and creating a new beneficence and averting the demage and danger sprung (Zuhaily, 1985). 
Islamic Sharia is the rules or religion laws (Islam) which relegated to his servants through the Prophet Muhammad, in the holy Quran and hadith forms that covering all areas. Sharia means is all laws forms established by God for His servants, has the properties as a religious duty that must be carried by everyone. God's Law remains the laws Lord, although nobody wants to enforce it. Even if Muslims were living outside of islam territory, they were bounded by the islamic laws (Supriyadi, 2007).

That comprehension it's in accordance with the creed (kredo) theory which presented by Juhaya, in Misno (2016), the creed Theory or shahada theory is a theory that requires the implementation of Islamic law by those who made the two sentences creed (of Muslims), as a logical consequence of it's pronunciation.

Sociologically, Islamic law has already been applied in Indonesia because the Islamic law has already lived and develop on the society, since the Islamic kingdoms, the Dutch colonial period up to the independence period. Legally, the majority of Islamic law has been implemented. But it's principle application is gradually on the promulgation of Islamic law in Indonesia (Supriyadi, 2007).

According to the enforcement laws theorem, the legal community life may not necessarily be upheld, because the law that live on the communities it's also relies on the law enforcement community. According to the theory of law enforcement, that the society law will be erect depends on three sides: first, the material law (fiqh, fatwā and qanūn); The second, or law enforcement officials (judges, clerks, bailiffs, P3N and Lebai); and third, the legal consciousness of society. Therefore, the implementation of Islamic law can be seen on turning of material legal, law enforcement officials, and community legal awareness (Mubarak, 2006).

Mubarak said that one of the important issues in law areas is the law obedience choice and regulations that established by the state or compiled by the authoritative scholars. Selection adherence to state law and religion, especially when the difference provision contained on of jurisprudence books with the laws and regulations. Yet according to the rules that formulated by the scholars when the judge's decision on this case that the government has been established, then all the provisions which contrary to the judge decision should be not applied.

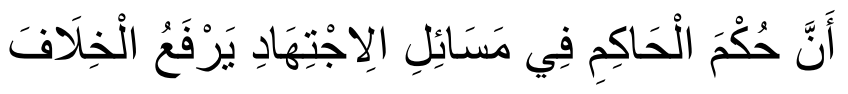

Imam al-Qarafi (1431 H/2010 M) clarifies that a muslim scholars which in contadiction views with judge decision it's ought to reconciliation on the matters of judge decision, it's mean when the society attitudes were consider the jurishfudence (fiqh) laws then the obligation rules, definitely it's in contradiction with theorem above.

This theorem is extendof islamic law explanation which carry out bythe bind up dominance anddoctrine of laws that proposed by the jurists. and it's also confirmed by Mukhlas when he explained that the legal norms which contained on the holy quran should be put in the law forms and regulations that bind many parties (Mukhlas, 2011), and it attachment is stronger because it has the institute device, that is courts.

The legal institutions of endowments is one of the islamic laws which was enacted. Basic Agrarian Law No. 5 of 1960 states that the principal provisions of endowments-owned land, which in Article 49 paragraph 3. which reads: that the endowments is protected and regulated on the government regulation. The government regulation was passed in 1977, i.e., Government Regulation No. 28 of 1977. In fact, the regulations on the endowments has existed since the colonial era, on circulars 
forms which distributed by the Dutch colonial administration. The circular letter which contains the commands for the regent to enrolled the worship houses on their area and for everyone who wants to donate their wealth should have prior permission from the regent.

In 1991 the president issued the Presidential Instruction No. 1 of 1991 on spreading the Islamic Law Compilation which consists of the three books. the endowments is set in the third book. In further developing it's passed a number of laws 41 of 2004 on the endowments matter followed by the Government Regulation No. 42 of 2006 on implementation Laws No. 41 of 2004.then the Indonesian endowments entities was formed in 2007 through a President decree Indonesian Republic Number 75 / M 2007. and BWI itself is an independent agency in his duty execution to develop the endowments in Indonesia. then BWI (draw up the rules that relating the endowments which guide the Indonesian Islamic community, for example, the endowments Regulation Board of Indonesia Number 3 of 2008 on the Registration and Nāẓir Replacement of Endowments Possessions is Not Moving on the Land forms and the endowments Regulations Board of Indonesia Number 2 Year 2010 concerning about Procedures registration of Nāẓir Endowments Money.

The laws establishment purpose Number 41 of 2004 on the endowments it's clearly conveyed in law explanations. and on it's explanation has already mentioned that one of the measures promoting general welfare are needed to enhance the religious role endowments as an institution that has an economically benefits. and it's also one of the objectives endowments itself. In addition, the legislation created to order, the continuance, and security of endowments property from a take over parties which against the law.

Nāẓir confessions of the endowments organizations and legal entities in the endowment legislationis one of the progress toward professionalism of the endowment's property managements. it's Impact extremely base on productivity and utilization that can be optimized on endowments property, including the quarrying products endowments and socialization processes into Islamic society.

The alterationsNāẓir of individual endowments to be nāẓir of institution endowments or legal entity is becomes necessary when the professionalism management and productivity of endowments property itself become the demands. When nāz̧ir endowments institutions and legal entities is not found in islamic terminology (figh), then extremely there was one rule that we believe in "la yunkarutaghayyuritaghayyuri bi al-Fatwa al-azman".

In Islamic law it's applicable to legal alteration, based on changing period and it's society. Ibn alQayyim (1423) has explained on his book about this laws theory alteration I'lām al-Muwaqi'in, he said:

$$
\text { تغير الفتوى و اختلافها بحسب تغير الأزمنة والأمكنة و الأحو ال و النيات و العو ائد }
$$

Legal issues and law alterations, definately, associated with a rules set that were held and executed by a society, a rule that controls human behavior as an ethic of community members (Manan, 2009).

Ibn al-Qayyim had build the alterations theory as a basis for maintaining legal purposes (maqāșid al-shari'a). in his theory that Ibn al-Qayyim mentions, five transcription factors, ie, the time factor, factor of circumstances, factors of interest, and cultural factors.

Ibn al-Qayyim basing his theory in fact, that a point of public beneficence at some places that might become the breakage on a period or somewhere else. Thus, the law characteristic it's phenomenally, which means it's case can be decided by a judge for a different decision, a reason 
being that there was the differences time, space, circumstances, goals and traditions (Muzarie, 2010).

The estuary of this laws alteration is turn back on the fulfillment of maqāṣid al-sharìa, to create the beneficence and estrange the damage matters, maslahah means as the benefit or an important thing that characteristicly practice. In the study of ushulfiqih the meaning of maslahah is giving law decision on a case which didn't have some naș or ijmā' based on take care of the beneficence or an important practice. Abdul Karim Zaidan interpreting the maslahah with double meanings, ie taking the beneficence and estrange the damage matters (Zaidan, in Muzarie, 2010).

In practice, such as described by Imam as-Syatibi in Mukhlisin Muzarie, that any legal decisions particularly regarding the worldliness that certainly contain the benefit things and damage because there is no purely legal that's purely benifits or damage (mafsadat). Therefore, the law concept has to consider the two of things (Muzarie, 2010).

Ibn Assyria explained that Islamic law on his totality it's manage the orderliness, in order that people can to comply their needs with ways of legality and respectable. Furthermore, the research results of Ibn Assyria suggested that the laws derived from the quran and Hadith that are found the concern clues on the asset managements and wealth and its utilization towards achieving the benefit of the world and the hereafter (Muzarie, 2010).

The relevance of mașlahah connections with law endowments is the realization of ta'bidu almanfaah on endowments property. Instead that the endowments relations with the damage (mafsadah) is reduced, damaged, or even loss a ra's al-māl of endowments or in the technical terms of endowments it's called as 'ayn al-waqf'.

In Caliph Hisham ibn 'Abd al-Malik period $(125 \mathrm{H})$ it's start to set up one of agency in charge on endowments property. The Council is collating data endowment sproperty of Muslims for endowments property beneficence and the interests of people who entitled upon the endowments property result. Since that, the endowments property is under government stewardship. The government is obliged to preserve the endowments property and manage the results as intended. This is the history beginning as well as the state role in maintaining endowments property (Dasuqy, 1427).

On the Ottoman dynasty period it's began to forming some institutions that take care of the endowments property (Rothstein \& Broms, 2013). On this period that began to drafted the endowments legislation as already mentioned previously. The laws governing the endowments property utilization. The endowments development was continued as far as the $12^{\text {th }}$ century of Hijri. In 1949 Syria had made the laws that memoratorium endowments expert. This step was followed by Egypt which passed the legislation in 1952 that prohibits the endowments expert. In 1955. Then Iraq was eliminate the endowments expert. This is done for the family benefit due to the tendency of the constributor (wāqif) nowdays, when about donating his wealth aim to stop one family member to seek redress for the legacy left of wakif. Those attitude is certainly incompatible act with shari'ah. For the beneficiary's reasons, it's ban becomes feasible to enforce.

The take over of management rights by the state endowments was carried out in Morocco after country's independence. In Libiya, the endowments property is managed by a special agency to manage endowments property and charity (zakāh). In Indonesia, the agency that manages formed the endowments property is called as Indonesian endowments Board 9 (BWI), with the law mandate Number 41 of 2004 on endowments. 
Repeating what was said before, in the endowments context. the jurists have formulated the requirements with the aim to realize the benefit of all parties. The endowments parties in implementing his pledge it's required to an adult person. This is to create the benefit and avoid the damage matter that given by the endowment practice on economics aspect isa disservice act, that regardless property rights.

Therefore, the children are not able to carry out the endowments practice because for his actions weren't can be accounted for. Similarly, for those people whose sick or unhealthy mind recollection, either because of serious illness or old age (senile), must not carry out the practice of the endowments (Dasuqy, 1427)

The treasure that contribute is required that must be an objects didn't moving or moving objects that have a sustainable character. For beneficiaries of endowments (mawqüf 'alayh) the requirements have to be clear and unequivocal, for example for the person, or people, or certain institutions in order for the target endowment is accordance with the objectives of Islamic law (maqāșid al-sharīa) that creating the benefit and avoid the damage things, both the world and the hereafter (Dasuqy, 1427).

For wealth endowments managers (nāzir endowments) as previously described that the defined terms which were all aimed for the benefit realization both endowments objects as well as for the endowment recipient, then the asset endowments can be preserved and developed.

The practice of Umar bin khattab who raised his good family member to be a nāzir is one of effort form to realize the benefit of endowments. Moreover, when it's looking at Umar's reason that he asked for the Prophet Muhammad opinions on its soil is because umar's land wasn't managed and untapped result. Therefore, to optimize the land potential, the Prophet advised him to rendering his land. Based on it, that will be no sense if it were handed to be managed by the ignorant people,incompetent, and does not mandate that it actually worsen the condition of the land.

The exposure above was reinforce the principle of the beneficence (mașlaha) as a consideration of the endowments dynamics laws. That's, the purpose of a various formulation legal provisions endowments is to maximize the benefit of endowments property through an optimal management without damaging staple of endowments property.

The beneficence principle it is could be the alteration reason or nāzir commutations. A nāẓir could be replaced when he indicated to do something that begotten in the damage matters of endowments property, or for their greater benefit as previously described.

Based on figh indeed, there was a various opinions related to the nāzir alteration This difference could be found on tafwidh discussions. BrieflyTafwidh itself means: leaning rights management of endowments into others. Generally the jurists noticed that nāzir is not allowed to delegate his status to others, or bequeath it, even if a wakip has set it (Wizarat Al-Awqaf Al-Kuwaitiyyah, 2006). Hanafiyya argued, there was three conditions of relating the tafwidh laws. First, if the transfer is done by the first people who give his nāzir rights, such as wakif or judge, officially it is permissible. Secondly, if the initial nāẓirs appointed by wakif, without having rights to bestow his nāzir status, but he wants to delegate it for the illness reasons that might cause him died, then it is permissible even without the judge permissions. 
Malikiyyah argued, basically this tafwidh it's only may be done by wakif itself. A nāẓir has no competents to bestow his status on others people except by wakif permission. This is similar to what was presented by Syafi'iyyah. They found that tafwidh should not be made unless if there was a provision (wāqif requirements) it's clear. For a nāzirr, he can't release his nāẓir status, even though if he did it, basically it is not valid.

According to Hanabilah, tafwidh is not allowed if it is done by appointed nāzir with the wakif or by the judge unless if there was a provisions. As if a nāziri it is mawqūf 'alayh and judges, and they also can bestow his nāzir status for others people, as they pleased in accordance with the benefit consideration (Abu Zahrah, n.d.).

Thejurist opinions above are basically it's not based on the qath'i proposition (al-Quran and Hadith), whole of it is built on the fighiyyah comprehensions which may be vary between one place and a different time. However, the estuary remains is also same, ie maintaining the benefit continuity of endowments property and his beneficence (mașlaha).

The research conducted by Djatnika et al. concluded that nāzir institutions or legal entity is better, more effective, tend to be more professional, and has a development program that is proportional, and more co-ordinated program oprasionalist through the policies that were collectively (Djatnika, 2000). The fact shows that the nāzir is generally consists of people who didn't has the adequate ability and their moonlighting, not as workers who are specifically tasked with managing endowments (Muzarie, 2010).

Itconclusion that can be used as the delegation booster of management rights on nāzir individual endowments to nāzirir institution nowdays it's known as the endowment institutions, or the institutions to the larger organizatio for obtaining a greater benefit.

BWI Regulation No. 2008 generally has already set the alteration process or nāzir commutations. In Article 3, paragraph 1-4 states that, 1) the removal and replacement nāzir conducted by BWI, 2) In the nāẓir replacement event, BWI has issued a decision of nāẓir regarding reimbursement, 3) According to a decree on nāẓir replacement, a nāzir is obliged to take care of the authenticationin letters in local KUA (Kantor Urusan Agama [Religious Affairs Office]).

\section{Implications of Nāzir Alteration}

PERSIS ([Persatuan Islam] Islamic Unity) as an organization, has a nāẓir endowments device on staff structure, prior to the Law No. 41 of 2004 on Wakaf passed has received a number of waqf of property received directly from wakif. Until now persis is exactly manage the endowments property land area of 2,352,696.04 m2 spread over 2257 locations throughout Indonesia.

The endowments property that has been recently certified as an area of $492,880.68 \mathrm{~m} 2$ or 544 certificate endowments, remainder of its, there were a pledge to reach the phase endowments, news agenda, and were still in the process of delivery. from it number, are mostly obtained from wakif, and a small donations number of land it received from the delegation management of endowments property rights of other nāzir.

Endowments property management responsibilities was handed over to arable fields that dealing with the endowments matter. In the management structure of Jam'iyya PERSIS is called as a Field endowments process (furthermoreits called as a Bidgar [Bidang Garapan/ Field of Work] 
endowments). A Bidgar endowments at the central level of PERSIS leadership under Maliyah sector coordination.

The endowments property of PERSIS at the end of the previous year, ie in 2012 covering an area of $2,279,433.36 \mathrm{~m} 2$ spread over 2167 locations. If you look at the total number of endowment's property in 2013 with the previous year, then we could see the the addition on endowments property of PERSIS from 2012 to November 2013 as many as 90 locations with an area of $73262.68 \mathrm{~m} 2$ (seventy-three thousand two hundred and sixty-two points sixty-eight square meters).

Endowments land, there was gained from wakif directly, and also obtained from the operation results of the organization, and also obtained from the management rights transfer of other Nāzir endowments. There are three locations of the PERSIS endowments obtained from liquidation or rather devolution of management rights endowments which sampled in this study, there area: a) the at-Tawheed Mosque located in Kp. PasirKoja, RT 02 RW 04, Babakan Ciparay, Bandung, b). Firdaus islamic boarding which located in Margamekar village, Pangalengan subdistrict, Bandung district, c) Al-Fitri Islamic Boarding School which is located at Pangkalan village. Base Village RT 02/08 Cipinang, Cimaung subdistrict, Bandung district.

Before the devolution, Al-Fitri Islamic Boarding School, previously is called as Hidayatul Islamiyyah Boarding School at the beginning of its establishment until the increasing of student devolutions. But in a boarding school educational facility did not experience much change. Even the school management had not been gradually improved, especially in the islamic boarding school's financial regulatory system. In fact, according to the respondents, leading to the using financial interests for the personal interests of Islamic Boarding School.

This is the different conditions on Firdaus Islamic condition, in a physical facility was experienced some progress. Islamic boarding school has doing some construction, including the construction of mosques and development classes. But in the number of students, Firdaus schools was suffered a significant setback. This indicates declining public confidence in the boarding school. It also includes the managers of boarding wakif confidence was declining, indicated by decreasing theassistance amounts thatgiven by wakif. Additionally, the management schools had not been settled with the maximum. As for the at-Tawheed mosque which was founded in 1967 with th condition of the building stage or often called tajug, then became a permanent building with a permanent wall that made of a mixture of sand, bricks, and cement. After that, Tauhid mosques is not making progress such as the benefit activities to prosper the mosque. Teaching activities are not routinely performed. the Mosque is only used for religious activities and teaching of diniyyah students. Fundraising activities that were also relatively not run as expected.

The mosque developments its only existence on islamic elementary school (Nuruzzaman) which built on Mr. Ahmad Hidayat's land. Its location was located far apart from Tauhid mosque so it may not be apparent that the school was affiliated to the mosque. Even after Mr. Ahmad Hidayat was settle in a new place, the school also migratory and automatically switch off its relevance with the mosque. After Nāzir delegation, from the three of endowments locations which sampled in this research, according to the submitted by the respondents, all expressed the significant change towards better things. For example, Al-Fitri Islamic boarding school, was progressed on School managements, the construction of new classrooms, and the expansion of islamic boarding school's land. Which was obtained from the new land endowments that comes from a wakif although it has not worked optimally. The donated land has an area of about 60 tumbak/ (840 M2). 
Al-Fitri islamic boarding schools was build the three new classrooms, one local its from the central leadership of Islamic Association funds, and the two classrooms of RKB (ruang kelas baru/new classrooms) funds which provided by the government. The addition of student numbers who enroll its also gradually increased. Although at the beginning its occured the degradation of student which was resulted by the migration of student to the new schools that established by the old board. This indicates a growing confidence around an Islamiccomunity was another factor of progressing boarding. Even after the delegation, the students who enroll in Al-Fitri boarding school is not only from the surrounding community, but also from the District outsides of Cimaung even from city outside of Bandung. Thoat'soccured because the communications network that does not directly formed from the Union of Islamic boarding school members who promote it. In addition, Al-Fitr Islamic boarding school its also has a land that used for the productive land in three locations. The results of productive land managements is used in operational boarding. In one of the harvest advances, from one location to be had on average 1.5 million rupiah. Even fore Al-Fitrilslamic boarding is planning to erect a building that will used or leased as a business place on the owned boarding land. its idea came, as previously described that a boarding school manager saw that the opportunities strategic location which is right alongside at main road leading to the tourist attractions are located in the District Cimaung and Pangalengan. If these plans materialize, it would be a significant progress in terms of both physical infrastructure and in terms of income schools.

The Progress it is looked at Firdaus boarding school. The most important progress that according to the respondents isa wakif credence especially in the boarding schools and the society generally re-grow. Its was evidenced by the increasing number of public participation in public events held on boarding as public recitation and ied prayer. In addition, the number of high class students and senior high student (Aliyyah \& Dinniyyah) gradually rise.

The Relative increase of student on Firdaus boarding school is inseparable from the members role of the Islamic Association in the district and the Central Executive of PERSIS at Pangalengan. The PERSIS members who were in the congregation its also participate in promoting Firdaus boarding. Even before the devolution, that the caretaker of Firdaus boarding school is an active member of the Islamic Union and the pioneering leadership of PERSIS in several locations in Pangalengan which is not far from the boarding. Like wise with the Central Leadership that promotes his boarding school.

Because a wakif reliance against the boarding school is grow back, did not fade long, the funding from a wakif and families is provided to the schools for the school's physical development and mosques. Its assistance is money form, which has reached on this year Rp. 180,000,000. Additionally, a wakif has contributed regularly to 600,000 rupiah per month.

Schools facilities is also had made a little progress, among them is toilet school constructions, the construction building that block the water flows that sometimes overwhelm the boarding school in the rainy season, the generator procurement as a electrical sources energy of schools for 13 million rupiah, the procurement of carpet mosques, as well as new classrooms, the following students learn tables and chairs, as well as the lighting boarding procurements, which deplete the funds up to 15 million rupiah.

According to respondents, the progress was visible from the school management, particularly on financial management. It is seen from the division of management schools ranging from mudir 'am, mudir, mu'alimin, mudirtsanawiyyah, and competent teachers. Currently the office mudir 'am schools which led by cleric Qamarudin Salih, who is also the secretary of the Central Executive BidgarDa'wa Islamic Union. 
The Curriculum developed by the Leadership Centre at the Islamic Association at each level used either on firdaus boarding school or Al-Fitri boarding school, and it is run after the two schools affiliated to the Central Board of Islamic Unity. Its curriculum was integrated with the curriculum developed by the Education ministry. The curriculum combinations was providing a balance matter between the academic charge of religion study in those schools and general knowledge charge, Even the religious charge is relatively has a good quality than those are prepared by a religion ministry.

At-Tauhid Mosque has underwent the significant progress both in the breadth of the following buildings, the number of jam'aah, activities and revenue mosque. what was mentioned in the previous sections on existing activities in at-Tauhid Mosque either devotional, educational, social and charitable fundraising all happen after the change or replacement.

The establishment of Nurul Imanis lamic elementary school as already described previously, was carried out after nāzir alteration.the kindergarten (Raudhatul Athfal) and Nurul Iman boarding school and its mosque is on of the developments on education sector. This Mosque is progressing in the public confidence charity Distribution ( zakat), donation and alms (shadaqah) entrusted by many people in the environment around the mosque, even according to DKM (Dewan Kemakmuran Mesjid/Council of Mosque Prosperity), there was a schedule of charity setting (zakāt al-fițr) between the political village and mosque seeing more people who more entrusting into the mosque.

Public confidence to its mosque was directly proportional with mosque opinios, both its status as a charity, donation, and alm (șadaqa). Nominal income per month (kencleng/Money container) that the author convey in the previous section is a monthly income that occurs after the alteration its happen. Mosque Progression was visible in the mosque building. The second floor of At-Tauhid mosque was built to fulfill the society needs. Then the mosque was expanded which was originally only 10 to $13 \mathrm{M} 2$ (tumbak) and the renovation was routinely done every year, whether it be painting or remodeling lightweight wall or roof of the mosque.

\section{CONCLUSION}

From the previous description there are some conclusions that can be drawn: The status alterations and nāzir positions of endowments according to Jurisprudence and legislation is allowed, including nāzir alterations either from the individual to individual, individuals to institutions, from the institutions to individuals, or from the institutions to individuals. This was based on Indonesian endowments Board Regulations on the procedure for registration and the commutation of nāzir endowments. According to any Islamic Jurisprudence, nāzir alterations is recognized and can be done when the government or wakif were seen any benefit from these alterations, or when origin Nāzir does not perform its function properly, or even misuse it.

The implications of alterations nāẓir endowmentsis impacted on optimizing management and productivity of endowments property. It can be looked from the implementation of status alterations and position of nāzir endowments that occur in the organizations of Islamic union which evidenced by the increasing of output or optimization function and its management before there was its alterations on nāẓir itself. 


\section{References}

Ab Hasan, Zunaidah; Othman, Azhana; Ibrahim, Khalilah; Shah, Mohd Ab Malek Md \& Noor, Abd. Halim Mohd. (2015). "Management of Waqf Assets in Malaysia". International Journal of Nusantara Islam, Vol .03 No .01, pp. 59-69, http://dx.doi.org/10.15575/ijni.v3i1.412

Abu Zahrah, Muhammad. (n.d.). Muhāạdarah fĩ al-Waqf, Beirut, Jami'atu al-Duwal al-'Arabiyyah.

Ahmed, Habib. (2011). "Maqāșid al-Sharīa and Islamic Financial Products: a framework for assessment". ISRA International Journal of Islamic Finance, 3 (1). pp. 149-160.

Al-Dasuqy, Muhammad al-Sayyid. (1427 H). Walāyat al-Dawlah 'alā al-Waqf, Makkah Mu'tamar alAwqaf al-Tsani.

Al-Qarafi. (1431 H/2010 M). Anwār al-Burūq fĩ anwa’ al-Furūq, Kuwait, Dar Al-Nawadir.

Ali, Mohammad Daud. (1990). Hukum Islam: Pengantar IImu Hukum dan Tata Hukum Islam di Indonesia, Jakarta, Raja Grafindo Persada.

Athoillah, Mohamad Anton. (2013). "Zakat as an Instrument of Eradicating Poverty (Indonesian Case)". International Journal of Nusantara Islam, Vol. 1 No. 1, pp. 73-85; https://dx.doi.org/10.15575/ijni.v1i1.37

Babacan, Mehmet. (2011). "Economics of Philanthropic Institutions, Regulation and Governance in Turkey". Journal of Economic and Social Research, Vol 13(2), pp. 61-89.

Chowdhury, Md. Shahedur Rahaman; Ghazali, Mohd Fahmi bin \& Ibrahim, Mohd Faisol. (2011). "Economics of Cash WAQF management in Malaysia: A proposed Cash WAQF model for practitioners and future researchers". African Journal of Business Management, Vol. 5(30), pp. 12155-12163. https://dx.doi.org/10.5897/AJBM11.1810

Diharto, Awan Kostrad. (2016). "Revitalization through Innovation Waqf Property Traditional Development". the International Journal of Business \& Management, Vol 4 Issue 9, pp. 240243

Djatnika, Rahmat, et. al., (2000). Pendayagunaan Perwakafan Tanah Milik di Bandung Jawa Barat, Bandung, Intitut Agama Islam Negeri Sunan Gunung Djati Bandung.

Drafting Team, Wizarat Al-Awqaf Al-Kuwaitiyyah. (2006). Al-Mawsū'ah al-Fiqhiyyah al-Kuwaitiyyah, Kuwait, Wizaratu al-Auqaf.

Dusuki, Asyraf Wajdi and Abdullah, Nurdianawati Irwani. (2007). "Maqasid al-Shari ah, Maslahah, and Corporate Social Responsibility". the American Journal of Islamic Social Sciences, $24: 1$.

Hashish, Adham A. (2010). "Ijtihad Institutions: The Key to Islamic Democracy Bridging and Balancing Political an Intellectual Islam". Richmond Journal of Global Law \& Business, Vol. $9: 1$.

http://www.persatuanislam.or.id/home/front/detail/profile/sejarah-singkataccessed on May 5, 2014. 
Ibnu al-Qayyim al-Jauziyyah. (1423 H). l'lām al-Muwaqiīn, Riyadh, Dar Ibn Al-Jauzi.

Manan, Abdul. (2009). Aspek-Aspek Pengubah Hukum, Jakarta, Kencana Prenada Media.

Misno, Abdurrahman. (2016). Reception Through Selection-Modification: Antropologi Hukum Islam di Indonesia, Yogyakarta, Deepublish.

Mohamad, Noraini \& Zulkifli, Zahanum. (2015). "The Role of Higher Institutions in Creating Awareness on Challenges of MUIP in Communicating its Waqf Possession". International Journal of Nusantara Islam, Vol. 03 No. 01, pp. 69-76, http://dx.doi.org/10.15575/ijni.v3i1.413

Moustafa, Tamir. (2014). "Judging in God's Name: State Power, Secularism, and the Politics of Islamic law in Malaysia". Oxford Journal of Law and Religion, Vol. 3, No. 1 (2014), pp. 152167, https://dx.doi.org/10.1093/ojlr/rwt035

Mubarak, Jaih. (2006). Hukum Islam: Konsep, Pembaruan dan Teori Penegakan, Bandung, Benang Merah Press.

Mukhlas, Oyo Sunaryo. (2011). Perkembangan Peradilan Islam: dari Kahin di Jazirah Arab ke Peradilan Agama di Indonesia, Bogor, Ghalia Indonesia.

Muzarie, Mukhlisin. (2010). Hukum Perwakafan dan Implikasinya terhadap Kesejahteraan Masyarakat, Jakarta: Kementrian Agama Republik Indonesia (Ministry of Religious Affairs, Republic of Indonesia).

Peraturan BWI (Indonesian Waqf Board Regulation). (2008). No. 3 tentang Tata Cara Pendaftarandan Penggantian Nāẓir Harta Benda Wakaf Tidak Bergerak Berupa Tanah.

Peraturan BWI (Indonesian Waqf Board Regulation). (2010). No. 2 tentang Tata Cara Pendaftaran Nāẓir Wakaf Uang.

Peraturan Pemerintah (Government Regulation). (2006). No. 42 tentang Pelaksanaan Undangundang Nomor 41 year 2004 tentang Wakaf.

Purwanto, Yedi; Utomo, Hari \& Noor, Rasyida. (2016). "Naẓīr Al-Waqf in Imām Shafi'i's Perspectives and Regulation in Indonesia". International Journal of Nusantara Islam, Vol. 04 No. 01, pp. 49-62, http://dx.doi.org/10.15575/ijni.v4i1.1202

Rosadi, Aden \& Athoillah, Mohamad Anton. (2015). Distribusi zakat di Indonesia: antara sentralisasi dan desentralisasi". Ijtihad, Jurnal Wacana Hukum Islam dan Kemanusiaan Vol. 15, No. 2, pp. 237-256, https://dx.doi.org/10.18326/ijtihad.v15i2

Rothstein, Bo and Broms, Rasmus. (2013). "Governing religion: the long-term effects of sacred Financing". Journal of Institutional Economics / FirstView Article / September, pp 1 - 22

Rozalinda. (2015). "The Economic Empowerment of the Ummah on the Basis of Productive Waqf in West Sumatra, Indonesia". International Journal of Nusantara Islam, Vol .03 No .01, pp. 31-46, http://dx.doi.org/10.15575/ijni.v3i1.314 
Salarzahi, Habibollah; Armesh, Hamed \& Nikbin, Davoud. (2010). "Waqf as a Social Entrepreneurship Model in Islam", International Journal of Business and Management, Vol. $5(7)$.

Sirat, Abdul Hadi, Hilmiyah, Nurul and Shafiai, Muhammad Hakimi Mohd. (2016). Al Maslahah Based Quality Management: A Theoretical Overview". American Journal of Applied Sciences, Vol. 13 (3): pp. 243.250.

Supriyadi, Dedi. (2007). Sejarah Hukum Islam, Bandung: Pustaka Setia.

Undang-undang (Act) Nomor 41 Tahun 2004 tentang Wakaf.

Wahbah az-Zuhaili. (1985). Al-Fiqh al-Islāmī wa 'Adillathu, Damaskus, Dar al-Fikr.

Winarno. (2016). "Dinamisasi Hukum Islam: Suatu Pendekatan dalam Kerangka Metodologi Ushul Fiqh". Nurani: Jurnal Kajian Syari'ah dan Masyarakat, Vol 17, № 1, pp. 99-116, http://dx.doi.org/10.19109/nurani.v16i1.354.g620 